\title{
Onnistuneet pidot Aulangolla
}

Kanta-Hämeen kesäyliopisto ja Kansalais- ja työväenopistojen liitto järjestivät yhteistyössä aikuiskoulutuksen kehittämisorganisaation kanssa 7.-8.6.1982 Aulangolla symposiumin "Uudistuva aikuiskoulutus"'. Tilaisuuden nimi viittaa siihen, että aikuiskoulutus uudistuu luonnon voiman tavoin ja että ihmisten pitäisi seurata sivusta tätä uusiutumista. Järjestäjien tarkoitus oli kuitenkin aivan päinvastainen. Haluttiin nimittäin, että osanottajat saisivat kokonaiskuvan siitä, mitä on tapahtumassa siinä suunnittelussa, joka on meneillään valtion toimesta. Toisaalta haluttiin, että saamansa kokonaiskuvan sekä ennen muuta laajan asiantuntemuksensa mukaisesti aikuiskoulutuskentän edustajat lähettävät 'terveisiä' valtion toimikuntien jäsenille siitä, mihin suuntaan kehitystä pitäisi tulevaisuudessa viedä.

Jotta meneillään olevasta suunnittelusta voisi saada jonkinlaisen kokonaiskuvan, tarvittiin siihen kymmenkunta - siis aika monta - alustuspuheenvuoroa aikuiskoulutuksen eri näkökulmista. Ja merkillistä kyllä alustajat todella pitäytyivät heille annettuun puolen tunnin aikaan, tilaisuus pysyi tältä helpoimmin haavoittuvimmalta osin hyvin aikataulussa ja - mikä tär- keintä - esitysten perusteella, sen useat osanottajat toivat välittömästi julki, syntyi todella yleisnäkemys kehittämisorganisaation työstä.

Alustukset siis loivat hyvän perustan eriytyneelle työskentelylle. Sitä vahvisti vielä se, että kolmessa ryhmässä oli kussakin oma alustuspuheenvuoro, joka käsitteli ryhmän pääteemaa. Eriytynyt ryhmätyöskentely tapahtui ammatillisen aikuiskoulutuksen, vapaan sivistystyön sekä aikuiskoulutuksen hallinnon jaostoissa. Kanta-Hämeen kesäyliopisto (puh. 917-22 562) julkaisee jaostotyön tulokset, niin että tässä yhteydessä voidaan rajoittua vain toteamaan niiden erittäin korkea asiantuntemus. Jaostotyöskentely moninaisine keskusteluineen ja erinomaisine tuloksineen muodostui symposiumin parhaimmaksi osaksi, jonka konkreettiset kehittämisehdotukset on kirjattu kesäyliopiston laatimaan loppuraporttiin.

Yksittäisistä esityksistä mainittakoon tässä Aikuiskoulutuksen johtoryhmän puheenjohtaja Pentti Öhmanin alustus aikuiskoulutuksen kehittämislinjoista. Koska muodollisuuksista huolimatta kyseessä oli henkilökohtainen - ei johtoryhmän virallinen - puheenvuoro, voitaneen puhua "Öhmanin ohjelmas- ta'. Lyhyesti sanottuna sen sisältö oli seuraava: kehittämisorganisaation työn tuloksena valmistuu useita mietintöjä, jotka yhteensä sisältävät huomattavan määrän uusia kustannuksia merkitseviä ehdotuksia. Tästä syystä uudistukset on ajallisesti porrastettava ja välttämättä pantava myös tärkeysjärjestykseen.

Loppupuheenvuorossaan symposiumin johtajana ollut Timo Toiviainen totesi mm., että mahdolliset uudistukset voivat tuntua kenttätasolla vasta vuosien kuluttua ja että siksi on tärkeää jatkaa kehittämistyötä perusyksikkötasolla jäämättä odottamaan kehittämisorganisaation työn mukanaan tuomia haasteita; niihin voidaan vastata sitä paremmin, mitä paremmin paikallistason kehittäminen on voitu järjestää.

Symposiumissa oli n. 75 osanottajaa, jotka tuntuivat olleen "Aulangon ensimmäisiin aikuiskoulutuspitoihin", tyytyväisiä. Ensimmäisistä pidoista oikeuttaa puhumaan se, että pitojen isäntä, kouluneuvos Esko Kangas piti mahdollisena vastaavanlaisten tilaisuuksien järjestämisen jatkamista juuri Aulangolla. Ensimmäisten pitojen pöytä oli niin hyvin katettu, että mielellään siitä nauttisi toisenkin kerran. 